\section{LOGALIZATION OF JOLIPEPTIN AND COLISTIN IN THEIR PRODUCING STRAIN, BACILLUS POLYMYXA VAR. COLISTINUS KOYAMA}

\section{Mikiko Ito and Yasuo Koyama}

Kayaku Antibiotics Research Laboratory, Funado, Itabashi-ku, Tokyo, Japan

(Received for publication December 21, 1971)

Bacillus polymyxa var. colistinus Koyama was well known as a colistin-producing strain which produced colistins A, B and $\mathrm{C}^{1,2)}$ extracellularly. Recently, it was observed that some kinds of peptide antibiotics were located within the colistin-producing cells, besides colistins $\mathrm{A}, \mathrm{B}$ and $\mathrm{C}$. They were named colistin $\mathrm{X}^{3)}$, jolipeptin ${ }^{4}$ and gatavalin ${ }^{5)}$, respectively, which were not excreted extracellularly.

Unlike protein synthesis, colistins $A$ and $B$ were biosynthesized in the supernatant fraction ultracentrifuged at $105,000 \times g$ without the participation of a ribosomal fraction $^{6,7)}$. Since the biosynthetic mechanism of the peptide antibiotics only intracellularly accumulated such as those above mentioned has been unknown as yet, we inquired whether they are synthesized by the same mechanism as in the case of colistin but exist in bound form as soon as they are synthesized or they are synthesized on the surface of any active particulates.

Along this line, the distribution of jolipeptin in the fractionated preparations of the bacterial cell homogenates was briefly surveyed.

The strain of Bacillus polymyxa var. colistinus Koyama and cultural conditions used in this paper were described in the previous paper $^{8)}$. Cells harvested at the middle of exponential growth phase, performing biosynthesis of colistin most actively ${ }^{9}$, were washed twice with physiological saline, suspended in $0.01 \mathrm{M}$ phosphate buffer $(\mathrm{pH} 7.2)$ containing $10 \mathrm{mM} \mathrm{MgCl}_{2}$ and $1 \mathrm{mM} 2$-mercaptoethanol and disrupted by a sonic oscillator at $10 \mathrm{KC}$ for 15 minutes. The disrupted cells were centrifuged at $18,000 \times g$ for 30 minutes. Further centrifugation of the re- sulting supernatant cytoplasmic fraction was carried out at $105,000 \times g$ for 120 minutes to yield a soluble fraction and a particulate fraction containing ribosomes. The sediment after centrifugation at $105,000 \times \mathrm{g}$, the particulate fraction, was suspended in the same buffer.

For the identification of intracellular antimicrobial substances, each fraction was subjected to paper chromatography and each activity applied to a paper was the same active quantity in terms of colistin units. Paper chromatography was developed using a solvent system of $n$-butanol, acetic acid and water ( $3: 1: 1$, by volume).

Detection of their active spots was carried out by bioautography on a plate of Escherichia coli NIHJ. Antimicrobial activity of each fraction was assayed by a paper disk method using $E$. coli NIHJ as test organism and tentatively expressed as colistin units. Gatavalin could not be detected in this experimental condition because of no inhibitory action against gram-negative bacteria.

As shown in Fig. 1, it is evident that jolipeptin is located only in the particulate fraction, the sediment after centrifugation at $105,000 \times g$, while colistins $\mathrm{A}, \mathrm{B}, \mathrm{C}$ and $X$ are found in the soluble fraction. The intracellular distribution of jolipeptin and colistin among various fractions obtained by centrifugal fractionation is summarized in Table 1.

All of the jolipeptin activity is located in the particulate fraction sedimented by centrifugation at $105,000 \times g$ for 120 minutes and about $60 \%$ of the total intracellular antimicrobial activity is located in this fraction. The antimicrobial activity was higher in the particulate fraction than in the soluble fraction. On the contrary, the major portion of colistin activities including colistins $\mathrm{A}$, $\mathrm{B}, \mathrm{C}$ and $\mathrm{X}$ are located in the soluble fraction and no components of the colistin group are found in the particulate fraction.

From the physico-chemical characteristics of jolipeptin described in the previous paper ${ }^{4)}$, jolipeptin does not seem to be a macromolecular substance capable of sedimentation at $105,000 \times \mathrm{g}$. Therefore, the data presented in this paper suggest that jolipeptin binds to particulates including 
Fig. 1. Bioautogram of each fraction obtained by centrifugal fractionation.

Solvent: $n$-butanol, acetic acid and water ( $3: 1: 1$, by volume).

Each active spot was detected by bioautography against Escherichia coli NIHJ.

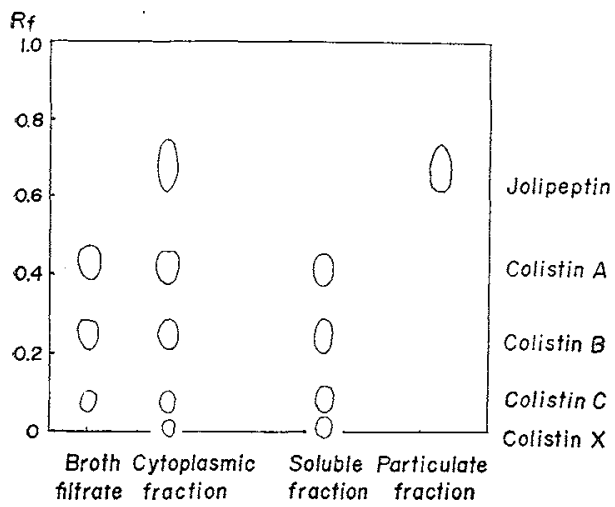

Table 1. Intracellular distribution of jolipeptin and colistin in Bacillus polymyxa var. colistinus KoYama

\begin{tabular}{l|r|r}
\hline \multicolumn{1}{|c|}{ Fraction } & $\begin{array}{c}\text { Total } \\
\text { activity } \\
\text { (units) }\end{array}$ & \multicolumn{1}{|c}{$\begin{array}{c}\text { Antimicrobial } \\
\text { substances } \\
\text { located }\end{array}$} \\
\hline Cytoplasmic & 13,680 & $\begin{array}{c}\text { Jolipeptin, } \\
\text { colistin A, B, C, X. } \\
\text { Soluble }\end{array}$ \\
Particulate & 5,600 & $\begin{array}{l}\text { Colistin A, B, C, X. } \\
\text { Jolipeptin }\end{array}$ \\
\hline
\end{tabular}

Cells used in this experiment were $650 \mathrm{mg}$ as dried cell weight. The activity was assayed using colistin sulfate $(21,000 \mathrm{~d} / \mathrm{mg})$ as standard and expressed as colistin units.

ribosomes and is present intracellularly in a bound form. If analogy is permitted, the fact that jolipeptin is distributed only in the particulate fraction may be suggestive of participation of some active particulates like ribosomes in jolipeptin biosynthesis.

In general, it has been confirmed that peptide antibiotics act primarily on cellular membranes and jolipeptin has the same action $^{10)}$. On the other hand, many investigations on the mode of action of some peptide antibiotics, such as, edeine ${ }^{11)}$ and siomycin ${ }^{12}$ ) have revealed that these peptide antibiotics act primarily by binding to ribosomes and inhibiting growth of the peptide chain in the cell-free system of their sensitive organisms. However, it has not been described as yet that peptide antibiotics are located themselves in ribosomes of the antibiotic producing cells. It must be pointed out that the present experiments do not prove that jolipeptin binds definitely to ribosomes. If jolipeptin binds definitely to any site of the ribosomes, it is assumed that it may have effects on cellular protein synthesis, besides the action against cellular membrane. The evidence presented in this paper is interested in the role played by these peptide antibiotics in the physiology of antibiotic-producing cells. Further studies are in progress on the mechanisms of biosynthesis of these antibiotics.

\section{References}

1) Koyama, Y.; A. Kurosawa, A. Tsuchiya \& K. Takakuta: A new antibiotic 'colistin' produced by spore-forming soil bacteria. J. Antibiotics 3: 457 458, 1950

2) ODA, T.: M. Kinoshita, O. Yamanaka \& F. UEDA: Studies on colistin. I. Paper chromatography of colistin. Yakugaku Zasshi $74: 1243 \sim 1246, \quad 1954$

3) AIDa, T.; M. Iro \& K. Yamaguchi : Formation of colistin-like substance by disrupted cells. Proc. Ann. Meet. Agr. Chem. Soc, Japan p. 163, 1966

4) Iтo, M. \& Y. Koyama: Jolipeptin, a new peptide antibiotic. I. Isolation, physicochemical and biological characteristics. J. Antibiotics, in press.

5) NakaJima, N.: S. Chinara \& Y. Koyama: A new antibiotic, gatavalin. J. Antibiotics, in press,

6) Itro, M.; K. Aida \& T. Uemura: Biosynthesis of colistin by Bacillus colistinus Koyama. Biochim. Biophys. Acta 213 : 244 247,1970

7) Ito, M.; Y. Koyama, K. Aida \& T. Uemura : Biosynthesis of colistin by a cell-free system of Bacillus colistinus Koyama. Biochim. Biophys. Acta 215 : 418 420, 1970

8) Ito, M.; K. Aida \& T. Uemura: Studies on the bacterial formation of peptide antibiotic, colistin. II. On the biosynthesis of 6-methyloctanoic and isooctanoic acids. Agr. Biol. Chem. 33:262 269, 1969

9) Ito, M.; K. AIdA \& T. Uemura : Formation mechanism of colistin produced by Bacillus colistinus Koyama. Progr. in Antimicr. \& Anticancer Chemoth. (Proc. 6 th Internat. Congr. Chemoth.) $2: 1128 \sim 1137,1970$

10) Iто, M. \& Y. Koу Ama : Jolipeptin; A new peptide antibiotic. II. A mode of action of jolipeptin. J. Antibiotics, in press.

11) Kurylo-Borowska, Z. \& M. Hrerowski : On the mode of action of edeine. II. Studies on the binding of edeine to Escherichia coli ribosomes. Biochim. Biophys. Acta 95 : $590 \sim 597,1965$

12) Tanaka, K.; S. Watanabe, H. Teraoka \& M. TAMAKI : Effect of siomycin on protein synthesizing activity of Escherichia coli ribosomes. Biochim. Biophys. Res. Comm. $39: 1189 \sim 1193,1970$ 